\title{
Chemical Constituents of Eupatorium japonicum and Anti-Inflammatory, Cytotoxic, and Apoptotic Activities of Eupatoriopicrin on Cancer Stem Cells
}

\author{
Minh Giang Phan $\mathbb{D}^{1},{ }^{1}$ Thi Thao Do $\mathbb{D}^{2},{ }^{2}$ Thi Nga Nguyen $\left(\mathbb{D},{ }^{2}\right.$ Thi Viet Huong Do $\mathbb{D}^{1},{ }^{1}$ \\ Ngoc Phuc Dong $\mathbb{1},{ }^{1}$ and Minh Trang Vu $\mathbb{1}^{3}$ \\ ${ }^{1}$ Faculty of Chemistry, VNU University of Science, Vietnam National University, 19 Le Thanh Tong Street, Hanoi, Vietnam \\ ${ }^{2}$ Institute of Biotechnology, Vietnam Academy of Science and Technology, 18 Hoang Quoc Viet Road, Hanoi, Vietnam \\ ${ }^{3}$ VNU University of Education, Vietnam National University, 144 Xuan Thuy Road, Hanoi, Vietnam
}

Correspondence should be addressed to Minh Giang Phan; giangpm@vnu.edu.vn

Received 27 December 2020; Revised 18 March 2021; Accepted 16 April 2021; Published 18 May 2021

Academic Editor: Weicheng $\mathrm{Hu}$

Copyright (c) 2021 Minh Giang Phan et al. This is an open access article distributed under the Creative Commons Attribution License, which permits unrestricted use, distribution, and reproduction in any medium, provided the original work is properly cited.

\begin{abstract}
Eupatorium japonicum Thunb. of the plant family Asteraceae is a popular traditional herb in Vietnam. However, its chemical constituents as well as bioactive principles have not been investigated yet. We investigated the phytochemistry of E. japonicum in Vietnam and isolated seventeen compounds (1-17) including phytosterols, terpenoids, phenolic acids, flavonoids, fatty alcohols, and fatty acids. They were structurally determined by MS and NMR analysis. Except for compounds 6 and 12, all the other compounds were identified for the first time from E. japonicum. Since many sesquiterpene lactones with $\alpha$-methylene $\gamma$-lactone ring are reported as anti-inflammatory and anticancer agents, eupatoriopicrin (10), 1-hydroxy-8-(4,5-dihydroxytigloyloxy) eudesma-4(15),11(13)-dien-6,12-olide (11) were selected among the isolates for biological assays. Compound $\mathbf{1 0}$ was identified as the main bioactive sesquiterpene lactone of E. japonicum showing its potent anti-inflammatory and cytotoxic activity through inhibiting NO production and the growth of HepG2 and MCF-7 human cancer cell lines. For the first time, eupatoriopicrin (10) was demonstrated to strongly inhibit NTERA-2 human cancer stem cell (CSC) line in vitro. It is noticeable that the cytotoxicity of eupatoriopicrin against NTERA-2 cells is mediated by its apoptosis-inducing capability of $\mathbf{1 0}$ as demonstrated by the results of Hoechst 33342 staining, flow cytometry apoptosis analysis, and caspase-3 activity assays. The biological activities of the main bioactive constituents 1-7, 10, 12, and 15 supported the reported anti-inflammatory and anticancer properties of extracts from E. japonicum.
\end{abstract}

\section{Introduction}

In Vietnam, traditional herbal remedies are considered complementary or alternative medicines in the healthcare system. However, many herbal remedies are clinically used without any scientific evidence of their efficacy and safety. Since biological activities are the links between medicinal plants and their pharmacology and medicinal uses, we have investigated the chemical constituents and biological activities of common Eupatorium species used in Vietnamese traditional medicine such as E. fortunei [1] and E. triplinerve [2]. Among the compounds isolated from the genus
Eupatorium, a number of sesquiterpenoids have been proven to possess different levels of cytotoxic, anti-inflammatory, antifungal, antibacterial, and insecticidal activities [3]. E. japonicum Thunb. belonging to the family Asteraceae has been recorded as a medicinal plant in Vietnam, Japan, and China. Its leaves are used for the treatment of nausea, vomiting, indigestion, and diarrhea [4]. In Vietnam, the species is known under the name "Son lan" or "Yen bach Nhat" (ydvn.net) and distributed in the mountainous Sapa district of the Northwestern Lao Cai province. This perennial herb grows $1-2 \mathrm{~m}$ tall, blooms from August to September, and fruits from September to 
November. The whole plant and root of "Son lan" are used by Vietnamese people to treat cough after a cold, back pain due to cold, and irregular menstruation (ydvn.net) [5]. A very few chemical studies reported the isolation of coumarin and euponin (a guaiane-type lactone) [6] as well as the identification of pyrrolizidine alkaloids by mass spectrometry (MS) [7] from the leaves of E. japonicum. Forty years later, in a recent communication, 19 compounds were reported from the flowers of E. japonicum in China including coumarin, 2-hydroxy-2,6-dimethylbenzofuran-3(2H)-one, 1-(2-hydroxy-4-methylphenyl)propan-1,2-dione, subamone, $\left(7 R^{*}\right)$-opposit-4(15)-ene-1 $\beta, 7$-diol, gentisic acid, caffeic acid, 9-hydroxythymol, protocatechuic acid, trans-Ohydroxycinnamic acid, umbelliferone, quercetin, taraxasterol, 9-acetoxythymol 3-O-tiglate, taraxasterol acetate, linoleic acid, 9-angeloyloxythymol, stigmasterol, and palmitic acid [7]. The present study describes the first investigation of the chemical constituents of the leaves of E. japonicum in Vietnam which resulted in the isolation of 17 compounds of different polarities and structural classes ranging from fatty alcohol, fatty acid, monoterpene, sesquiterpene lactone, and phytosterol to phenolic acid and flavonoid glycoside. Except for compounds 6 and 12, all of the compounds were isolated and identified for the first time from E. japonicum.

Compounds derived from nature create prominent screening libraries for drug discovery. Owing to a vast reservoir of unexploited medicinal plants, the Vietnamese medicinal plants have the potential to offer compounds of various structural and stereochemical types for the screening of lead compounds [8]. The safety of ethanol extracts prepared from E. japonicum and Foeniculum vulgare was evidenced from a recent toxicity test in mice [9]. Stem extracts from E. japonicum suppressed lipid accumulation and inhibited the expression of adipocyte markers and coumaric acid and its methyl ester were isolated from the extracts as the bioactive components [10]. Extracts from E. japonicum exerted anti-inflammatory effects through the suppression of various molecular targets such as NO production, interleukin, iNOS, COX-2, MMP-9 transcription, NF- $\kappa$ B activation, and TRIF-dependent signaling pathway of toll-like receptors $[4,11,12]$. In addition, apoptotic effects through the ROS-induced ATF4 and CHOP expression [4] and antimetastatic effects through inhibiting cell migration, invasion, and adhesion of MDA-MB-231 human breast cancer cells in dose-dependent manners were observed for the extracts [13]. The major compounds responsible for these biological activities of E. japonicum have not been revealed yet. Since many sesquiterpene lactones with $\alpha$-methylene $\gamma$-lactone ring are reported to regulate antiinflammatory and anticancer targets $[14,15]$ in order to validate the biological effects of E. japonicum extracts in relation to its chemical constituents eupatoriopicrin (10), a germacranolide and 1-hydroxy-8-(4,5-dihydroxytigloyloxy) eudesma-4(15),11(13)-dien-6,12-olide (11), an eudesmanolide were selected for the study of NO-inhibitory activity and cytotoxicity against human cancer stem cells (CSCs). Being disclosed as cytotoxic, the mechanism of cell death through apoptosis induction on CSCs would be examined using
Hoechst 33342 staining, flow cytometry apoptosis analysis, and caspase- 3 activity assays on NTERA-2 pluripotent human embryonal carcinoma cell line.

Nitric oxide (NO) is a short-lived free radical derived from L-arginine by nitric oxide synthase (NOS) that mediates diverse functions by acting on various cells through interactions with different molecular targets. The excessive production of $\mathrm{NO}$ in prolonged inflammation can cause cellular and tissue damage. The adverse effect of this inflammation can be prevented by the intervention of antiinflammatory agents. Compounds able to inhibit the production of $\mathrm{NO}$ or other proinflammatory molecules are considered potential anti-inflammatory agents. CSCs are the cells that have the ability to self-renew, differentiate into defined progenies, initiate, and maintain tumor growth [16]. Despite being a small percentage in tumor cells, CSCs are present in most tissues including breast, brain, lung, head and neck, prostates, testis, ovary, esophagus, colon, and liver and play a role in cancer metastasis and therapeutic resistance, both of which are the major causes of cancer mortality and cancer recurrence [17]. There is evidence that the current chemotherapy for the treatment of cancer is insufficient in eliminating CSCs from a number of cancer types. The lingering CSCs are able to form new, fully developed tumors from a small number of cells or even a single cell. Therefore, recent studies target the discovery of natural drugs against CSCs involved in tumor development for different cancers [18]. Apoptosis is a highly regulated cell death process and occurs both during normal development and under certain pathological conditions. Apoptosis plays a crucial role in maintaining tissue homeostasis by the selective elimination of excessive cells. The evasion of apoptosis is an essential hallmark of cancer; therefore, killing cancer cells through the induction of apoptosis is a valuable tool for cancer treatment.

\section{Materials and Methods}

2.1. General Experimental Procedures. IR spectra were taken on an Affinity-1S FT-IR spectrometer. Electron-spray ionization-mass spectrometry (ESI-MS) spectra were measured on an Agilent 1100 LC-MSD-Trap-SL system (Agilent Technologies, USA) or Thermo Fisher Scientific LTQ Orbitrap XL ${ }^{\mathrm{MS}}$ mass spectrometer in $\mathrm{CH}_{3} \mathrm{OH}$ solution. ${ }^{1} \mathrm{H}$ NMR (SF 500.20 MHz), ${ }^{13} \mathrm{C}-\mathrm{NMR}$ (SF $125.13 \mathrm{MHz}$ ), and DEPT spectra were recorded in $\mathrm{CDCl}_{3}$ or $\mathrm{CD}_{3} \mathrm{OD}$ using a Bruker Avance 500 NMR spectrometer. The chemical shifts are expressed in ppm relative to tetramethylsilane (TMS) as an internal standard. Silica gel $40-63 \mu \mathrm{m}$ or $15-40 \mu \mathrm{m}$, reversed-phase C-18 silica gel (RP-18) 40-63 $\mu \mathrm{m}$ (Merck, Germany), and highly porous Diaion HP-20 (Mitsubishi, Japan) were used for column chromatography (CC). Precoated silica gel Merck $60 \mathrm{~F}_{254}$ aluminum plates were used for thin-layer chromatography (TLC). Lipopolysaccharide (LPS) from Escherichia coli was purchased from Sigma Chemical Co. (St. Louis, MO, USA). Dulbecco's Modified Eagle's Medium (DMEM) and fetal bovine serum (FBS) were purchased from Life Technologies, Inc. (Gaithersburg, MD, USA). Sodium nitrite, sulfanilamide, 
$N$-1-napthylethylenediamine dihydrochloride, dimethyl sulfoxide (DMSO), sulforhodamine B (SRB), 3-(4,5-dimethylthiazol-2-yl)-2,5-diphenyltetrazolium bromide (MTT), and 4-(2-hydroxyethyl)-1-piperazineethanesulfonic acid (HEPES) were obtained from Sigma Chemical Co. (St. Louis, MO, USA). All cell lines were a kind gift from Professor Domenico Delfino, Perugia University, Italy, while the pluripotent human embryonal carcinoma cell line (NTERA-2) was provided by Dr. P Wongtrakoongate, Mahidol University, Thailand.

2.2. Plant Materials. The leaves of E. japonicum were collected in Lao Cai province, Vietnam, in September 2016. The plant material was taxonomically identified by Dr. Nguyen Thi Kim Thanh, Faculty of Biology, VNU University of Science, Vietnam National University, Hanoi, and deposited at the same institution (voucher sample EJ-916).

2.3. Extraction and Isolation of Compounds 1-17. The dried powdered leaves $(2.0 \mathrm{~kg})$ of E. japonicum were extracted with $\mathrm{MeOH}$ at room temperature (3 times, each for 7 days). The combined $\mathrm{MeOH}$ extract was concentrated under reduced pressure, and the residue was successively partitioned between water and organic solvents of increasing polarities to give $n$-hexane- $(120 \mathrm{~g})$ and $\mathrm{CH}_{2} \mathrm{Cl}_{2}$-soluble fractions $(12 \mathrm{~g})$. The water phase was concentrated under reduced pressure to give a water-soluble fraction. The $n$-hexane- and $\mathrm{CH}_{2} \mathrm{Cl}_{2}$ soluble fractions were combined and a part $(66.7 \mathrm{~g})$ was separated by silica gel CC eluting with $n$-hexane-acetone 9 : $1,6: 1,5: 1,4: 1$, and $3: 1(\mathrm{v} / \mathrm{v})$ to give eight fractions. Fraction $1(3.09 \mathrm{~g})$ was separated by silica gel CC eluting with $n$-hexane-acetone $100: 1,50: 1$, and $1: 1$ to give a mixture of $\mathbf{1}$ and $2(5.0 \mathrm{mg})$ and a mixture of 3 and $4(5.0 \mathrm{mg})$. A mixture of 5 and $\mathbf{6}(20 \mathrm{mg})$ was crystallized from fraction 3 $(1.46 \mathrm{~g})$. Fraction $5(4.4 \mathrm{~g})$ was separated by silica gel CC eluting with $n$-hexane-EtOAc $15: 1,12: 1,9: 1,6: 1,3: 1$, and $1: 1$ to give five fractions 5.1-5.2. Fraction $5.1(1.2 \mathrm{~g})$ was separated by silica gel CC eluting with $n$-hexane-EtOAc 90 : $1,49: 1,25: 1,15: 1$, and $12: 1$ to give a mixture of fatty alcohols $(113.1 \mathrm{mg})$ and $5(105 \mathrm{mg})$. Fraction $5.5(1.2 \mathrm{~g})$ was separated by silica gel CC eluting with $\mathrm{CH}_{2} \mathrm{Cl}_{2}-\mathrm{MeOH} 30: 1$, $25: 1,20: 1,15: 1$, and $9: 1$ to give $7(7.5 \mathrm{mg})$. Fraction 6 $(22.8 \mathrm{~g})$ was separated by silica gel CC eluting with $n$-hexaneEtOAc $15: 1,12: 1,9: 1$, and $6: 1$ to give five fractions 6.1-6.5. Fraction $6.3(0.8 \mathrm{~g})$ was separated by silica gel CC eluting with $n$-hexane-acetone $15: 1$ to give $\mathbf{8}(5.7 \mathrm{mg})$. Fraction 6.5 $(4.7 \mathrm{~g})$ was separated by repeated silica gel CC using $\mathrm{CH}_{2} \mathrm{Cl}_{2}-$ acetone $15: 1,12: 1,9: 1,6: 1,3: 1$, and $1: 1$ to give a glycerol ester $(4.5 \mathrm{mg})$. Fraction $7(18.6 \mathrm{~g})$ was crystallized with acetone to give $9(86.1 \mathrm{mg})$. The residue was separated by silica gel CC eluting with $\mathrm{CH}_{2} \mathrm{Cl}_{2}-\mathrm{MeOH} 90: 1,49: 1,40: 1$, and $30: 1$ to give five fractions. Fractions 7.3 and 7.4 gave an insoluble solid in $\mathrm{CH}_{2} \mathrm{Cl}_{2}$. The solid was separated by silica gel CC eluting with $\mathrm{CH}_{2} \mathrm{Cl}_{2}$-acetone 9:1 to give $\mathbf{1 0}(29 \mathrm{mg})$. Fraction 7.3 was separated by silica gel CC eluting with $\mathrm{CH}_{2} \mathrm{Cl}_{2}$-acetone $9: 1,6: 1,3: 1$, and $1: 1$ to give $11(6.7 \mathrm{mg})$. The water-soluble fraction was passed through a Diaion HP20 column eluting with $\mathrm{MeOH}-\mathrm{H}_{2} \mathrm{O} 20,40,60$, and $100 \%$
$\mathrm{MeOH}$ to give four corresponding fractions. The 20\%$\mathrm{MeOH}$ fraction $(5 \mathrm{~g})$ was separated by silica gel CC eluting with EtOAc-MeOH 25:1, 15:1, 9:1, 6:1, 3:1, and $1: 1$ to give five fractions. Fraction 1 was purified by silica gel CC eluting with $\mathrm{CH}_{2} \mathrm{Cl}_{2}$-acetone $30: 1,25: 1,20: 1,15: 1,10: 1$, $5: 1$, and $3: 1$ to give $\mathbf{1 2}(2.0 \mathrm{mg})$. Fraction 2 was crystallized with $\mathrm{MeOH}$ to give $13(20 \mathrm{mg})$. The $40 \%-\mathrm{MeOH}$ fraction $(10 \mathrm{~g})$ was separated by silica gel $\mathrm{CC}$ eluting with $\mathrm{CH}_{2} \mathrm{Cl}_{2}$ $\mathrm{MeOH} 50: 1,25: 1,15: 1,12: 1,9: 1,6: 1$, and $3: 1$ to give ten fractions. Fraction 2 was separated by repeated silica gel CC eluting with $\mathrm{CH}_{2} \mathrm{Cl}_{2}-\mathrm{MeOH} 90: 1,80: 1,70: 1,60: 1,50: 1$, $40: 1,30: 1,25: 1,20: 1,15: 1,12: 1,9: 1,5: 1$, and $3: 1$ and then $\mathrm{CH}_{2} \mathrm{Cl}$-acetone $25: 1,20: 1,15: 1,12: 1,9: 1$, and $5: 1$ to give $\mathbf{1 4}(2.0 \mathrm{mg})$. Fraction $7(0.75 \mathrm{~g})$ was separated by silica gel CC eluting with EtOAc-MeOH 25:1, $20: 1,15: 1,12: 1$; $9: 1 ; 5: 1,3: 1$, and $1: 1$ to give $\mathbf{1 5}(85.8 \mathrm{mg})$. The $60 \%-\mathrm{MeOH}$ fraction $(17.9 \mathrm{~g})$ was separated by silica gel CC eluting with $\mathrm{CH}_{2} \mathrm{Cl}_{2}-\mathrm{MeOH} 35: 1,25: 1,15: 1,12: 1$, and $9: 1$ to give $\mathbf{1 0}$ $(69.6 \mathrm{mg})$ and $16(50.4 \mathrm{mg})$. The $100 \%-\mathrm{MeOH}$ fraction $(0.83 \mathrm{~g})$ was separated by silica gel CC eluting with $\mathrm{CH}_{2} \mathrm{Cl}_{2}-\mathrm{MeOH} 50: 1,25: 1,15: 1,12: 1,9: 1,6: 1$, and $3: 1$ to give five fractions. Fraction 2 was separated by silica gel CC eluting with $n$-hexane-EtOAc $70: 1,50: 1,25: 1,15: 1,12: 1$, $9: 1,7: 1,5: 1,3: 1$, and $1: 1$ to yield $17(2.0 \mathrm{mg})$. Fraction 4 was separated by silica gel CC eluting with $n$-hexane-EtOAc $70: 1,50: 1,25: 1,15: 1,12: 1,9: 1,7: 1,5: 1$, and $3: 1$ to yield a mixture of 3 and $\mathbf{4}(50.4 \mathrm{mg})$.

2.4. Cell Culture. All cell lines were seeded and cultured in DMEM medium with $2 \mathrm{mM}$ L-glutamine, $10 \mathrm{mM}$ HEPES, $1.0 \mathrm{mM}$ sodium pyruvate, and $10 \% \mathrm{FBS}$ in the incubator at $37^{\circ} \mathrm{C}$ and $5 \% \mathrm{CO}_{2}$. Cells were subcultured every 3 days at a 1 : 3 ratio.

2.5. Nitric Oxide Assay. RAW 264.7 cells were seeded to a 96well plate at a concentration of $2 \times 10^{5}$ cells/well. After incubation for $24 \mathrm{~h}$, the cultured medium was refreshed by DMEM without FBS. Then, the cells were treated with samples at different concentrations in the presence of LPS $\left(1 \mu \mathrm{g} / \mathrm{mL}\right.$ ) for $24 \mathrm{~h}$. $\mathrm{N}^{\mathrm{G}}$-Methyl-L-arginine acetate (LNMMA) (Sigma) was used as the positive control and the cells treated with a diluted solution of DMSO (1.0\%) were used as the negative control. Nitrite $\left(\mathrm{NO}_{2}^{-}\right)$, an indicator of NO production, was determined by the Griess reagent system (Promega Corporation, WI, USA). Briefly, $100 \mu \mathrm{L}$ medium was mixed with $50 \mu \mathrm{L} 1 \%(\mathrm{w} / \mathrm{v})$ sulfanilamide in $5 \%$ (v/v) phosphoric acid and $50 \mu \mathrm{L} 0.1 \%(w / v) ~ N-1$-naphthylethylenediamine dihydrochloride in a 96-well plate. The plate was then incubated at room temperature for $10 \mathrm{~min}$. The optical density (OD) was measured at $540 \mathrm{~nm}$ by using a microplate reader (Biotek, Winooski, VT, USA). The concentration of nitrite in each well was calculated by using the $\mathrm{NaNO}_{2}$ standard curve. The ability of NO inhibition of a sample was calculated by the following formula: (\%) inhibition $=100 \%-\left(\right.$ concentration of $\mathrm{NO}_{\text {sample }} /$ concentration of $\left.\mathrm{NO}_{\text {negative control }}\right) \times 100$. The value of $\mathrm{IC}_{50}$ (the halfmaximal inhibitory concentration) was determined by using 
the Table Curve 2Dv4 software (Systat Software Inc., San Jose, CA, USA) [19].

2.6. Cell Viability MTT Assay. The proliferation of cells treated with samples was determined by MTT assay [20]. $10 \mu \mathrm{L}$ MTT $(5 \mathrm{mg} / \mathrm{mL})$ was added to the wells containing $5 \times 10^{3}$ RAW 264.7 cells treated with samples and then incubated at $37^{\circ} \mathrm{C}$ for $4 \mathrm{~h}$. The purple formazan crystals formed by metabolically active cells were diluted by adding $100 \mu \mathrm{L}$ DMSO (100\%) to each well after removing the medium. The OD was measured by using a microplate reader (BioTek, Winooski, VT, USA) at $540 \mathrm{~nm}$. The percentage of cell viability was determined by the following formula: (\%) cell viability $=(\mathrm{OD}$ (sample) $-\mathrm{OD}$ (blank) $) /\left(\mathrm{OD}\right.$ (negative control) $\left.-\mathrm{OD}_{\text {(blank) }}\right) \times$ $100 \%$. All analyses were performed in triplicate and data were reported as mean \pm SEM (standard error of the mean).

2.7. SRB Colorimetric Assay. SRB assay was used for determining the cytotoxic activity of tested samples in a 96-well plate according to the method of Skehan et al. [21]. The test evaluates the cell density based on the measurement of the total cellular protein content stained with sulforhodamine B (SRB). Briefly, trypsinized cells were seeded in a 96-well plate and incubated with sample for $48 \mathrm{~h}$. The cell-containing wells treated with diluted solution serve as the negative control. After a period of incubation time, the cells were fixed with TCA for $1 \mathrm{~h}$ and then stained with SRB for $30 \mathrm{~min}$ at $37^{\circ} \mathrm{C}$. The plates were washed three times with acetic acid to remove all nonstaining dye and allowed to dry at room temperature. SRB staining protein in cells was dissolved in $10 \mathrm{mM}$ unbuffered Tris base and the plate was gently shaken for $10 \mathrm{~min}$ at room temperature. The OD at the wavelength of $540 \mathrm{~nm}$ was measured by using an ELISA plate reader (BioTek, Winooski, VT, USA)). The inhibition percentage of cell growth in the presence of the treated sample is determined by the following formula: $(\%)$ inhibition $=100 \%-\left(\mathrm{OD}_{(\text {sample })}-\mathrm{OD}_{(\text {day } 0)}\right) /$ $\left(\mathrm{OD}_{\text {(negative control) }}-\mathrm{OD}_{(\text {day } 0)}\right) \times 100$. The test was triplicated to ensure accuracy. Ellipticine was used as the positive control. The $\mathrm{IC}_{50}$ value was determined by using the TableCurve 2Dv4 computer software.

2.8. Hoechst 33342 Staining. The morphology of cell nuclei treated with samples was determined through Hoechst 33342 staining (Allen et al. [22]). NTERA-2 cells grew stable in a 6-well plate for $24 \mathrm{~h}$ before being treated with samples, the reference (camptothecin) or the negative control (DMSO 1\%). After $48 \mathrm{~h}$ of treatment, cells were fixed with formaldehyde $4 \%$ for $30 \mathrm{~min}$ and then washed with phosphate-buffered saline (PBS) before staining with Hoechst $33342(0.5 \mu \mathrm{g} / \mathrm{mL})$ for $10 \mathrm{~min}$. The morphological change of nuclei was observed under a fluorescence microscope at $350 / 461 \mathrm{~nm}$ (excitation/ emission). The apoptotic cells have brighter nuclei or fragmented chromatin.
2.9. Flow Cytometry Apoptosis Analysis. The flow cytometry protocol was performed using Kit Annexin V and PI/dead cell apoptosis ${ }^{\circledR}$ (Invitrogen, Thermo Fisher Scientific) according to Ngo et al. [23]. Basically, cells $\left(1 \times 10^{6}\right.$ cells $)$ treated with samples were collected after $48 \mathrm{~h}$ incubation and washed with PBS before staining with Annexin V-FITC for $15 \mathrm{~min}$. The cells were continuously stained with propidium iodide (PI) $(5 \mu \mathrm{L})$ in Annexin V binding buffer. Total 10.000 cells for each sample were analyzed using Attune NxT flow cytometer (Thermo Fisher Scientific, USA). The unaffected cells were PI-negative and Annexin V-negative, while the apoptotic cells were Annexin V-positive, and the necrotic cells were only positive for PI.

2.10. Caspase-3 Activity Assay. The experiment was performed using the caspase- 3 colorimetric assay kit (BioVision Inc., USA). Briefly, cells were grown in a 6-well plate for $24 \mathrm{~h}$ before they were treated with samples and incubated in a high-humidity $\mathrm{CO}_{2}$ incubator at $37^{\circ} \mathrm{C}$ for further $48 \mathrm{~h}$. Cells that were treated with DMSO $10 \%$ were considered the negative control. After the treatment period, cells were detached with Trypsin-EDTA and then washed with PBS. The cell pellet was lysed with $50 \mu \mathrm{L}$ lysis buffer from the kit on ice for $10 \mathrm{~min}$. The cell lysis solution was then reacted with $10 \mathrm{mM}$ DTT and $4 \mathrm{mM}$ DEVD-pNA and incubated at $37^{\circ} \mathrm{C}$ for $2 \mathrm{~h}$. Samples were read at $405 \mathrm{~nm}$ by using a microplate reader to determine the OD. Fold-change in caspase- 3 activity of the sample was measured by comparing with the OD of the negative control [24].

2.11. Statistical Analysis. The data were expressed as the mean of three replicate determinations \pm standard deviation (SD). Statistical comparisons were made with Student's test; $p$ values $<0.05$ were considered significantly different.

\section{Results and Discussion}

3.1. Isolation and MS/NMR Elucidation of Compounds 1-17. The $\mathrm{MeOH}$ extract from the leaves of E. japonicum afforded 17 compounds, a glycerol ester, and a mixture of fatty alcohols on successive liquid-liquid fractionation and repeated chromatographic separation on silica gel, RP-18, or Diaion HP-20. The structures of the compounds were identified as $\alpha$-amyrin acetate (1) [25], $\beta$-amyrin acetate (2) [25], $\alpha$-amyrin (3) [25], $\beta$-amyrin (4) [25], $\beta$-sitosterol (5) [25], stigmasterol (6) [25], $\beta$-sitosterol 3-O- $\beta$-D-glucopyranoside (daucosterol) (7) [2,3], behenic acid (8) [26], stigmasterol 3$O$ - $\beta$-D-glucopyranoside (9) [25], eupatoriopicrin (10) [27, 28], 1-hydroxy-8-(4,5-dihydroxytigloyloxy)eudesma4(15),11(13)-dien-6,12-olide (11) [29, 30], caffeic acid (12) $[31], \quad(2 E)-3-[2-(\beta$-D-glucopyranosyloxy)phenyl]-prop-2en-oic acid (13) [3], $p$-menth-1-ene-3,6-diol (14) [32], quercetin-3-O-rutinoside (rutin) (15) [33], quercetin 3-Omethyl ether (16) [34], and kaempferol 3,7, $4^{\prime}$-trimethylether (17) [35] which were determined by comparing their spectroscopic data (MS, IR, ${ }^{1} \mathrm{H}-\mathrm{NMR}$, and ${ }^{13} \mathrm{C}-\mathrm{NMR}$ ) with reported literature values. Compounds 1-5, 7-11, and 13-17 were isolated for the first time from E. japonicum (Figure 1). 


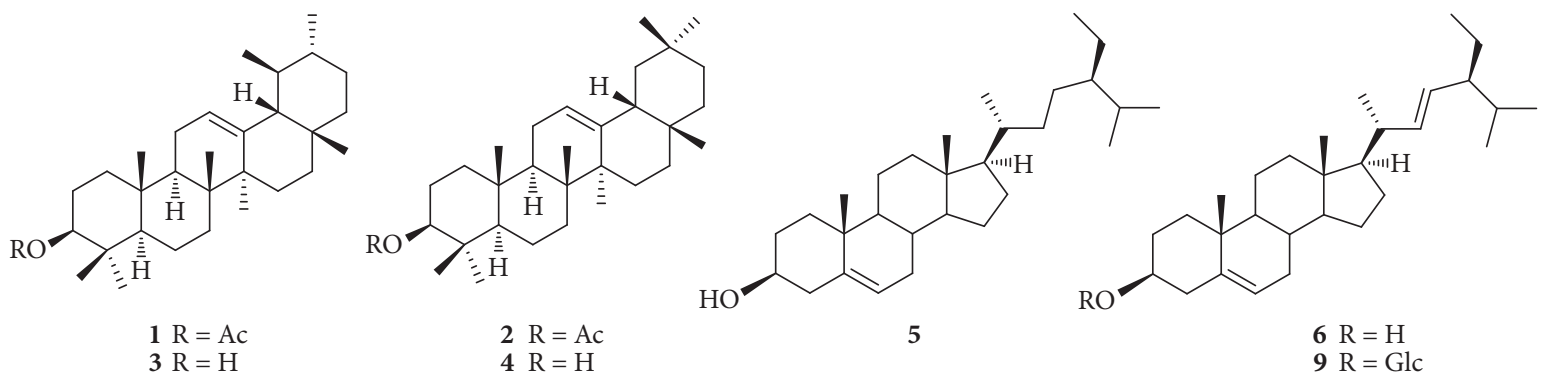<smiles>CCC(CC[C@H](C)[C@H]1CCC2C3CC=C4C[C@@H](O[C@@H]5O[C@H](CO)[C@@H](O)[C@H](O)[C@H]5O)CC[C@]4(C)C3CC[C@]21C)C(C)C</smiles><smiles>C=C1C(=O)O[C@@H](/C=C/C)C1[C@H](CC1=CCCC(C)=C1)OC(=O)/C(=C/CO)CO</smiles>

10<smiles>C=C1C(=O)O[C@@H]2[C@@H]3[C@H](O)CCC(=C)[C@@]3(C)C[C@H](OC(=O)/C(=C/CO)CO)[C@@H]12</smiles>

11<smiles>O=C(O)/C=C/c1ccccc1OC1O[C@H](CO)[C@@H](O)[C@H](O)[C@H]1O</smiles>

13<smiles>CC1=C[C@@H](O)[C@H](C(C)C)C[C@H]1O</smiles>

14<smiles>C[C@H]1O[C@H](OC[C@H]2O[C@H](Oc3c(-c4ccc(O)c(O)c4)oc4cc(O)cc(O)c4c3=O)[C@H](O)[C@H](O)[C@@H]2O)[C@H](O)[C@@H](O)[C@H]1O</smiles>

15<smiles>[R20]c1cc(O)c2c(=O)c(OCC)c(-c3ccc([R6])c([R])c3)oc2c1</smiles>

$16 \quad \mathrm{R}_{1}=\mathrm{H} \quad \mathrm{R}_{2}=\mathrm{CH}_{3} \quad \mathrm{R}_{3}=\mathrm{H} \quad \mathrm{R}_{4}=\mathrm{OH}$ $17 \mathrm{R}_{1}=\mathrm{CH}_{3} \quad \mathrm{R}_{2}=\mathrm{CH}_{3} \quad \mathrm{R}_{3}=\mathrm{CH}_{3} \quad \mathrm{R}_{4}=\mathrm{H}$

Figure 1: Structures of compounds 1-17.

\subsection{NO Production Inhibitory Activity of Compounds 10 and} 11. Nitric oxide (NO) participates in various responses of host resistance to various pathogens and joins to adjust various aspects of life such as vascular integrity, maintains hemostasis, or modulates neural activity [36, 37]. The overproduction of NO induced pathological problems related to acute and chronic inflammatory, apoptosis and necrosis, or neurodegenerative diseases [38, 39]. RAW 264.7 cells activated by LPS produce large amounts of NO. Therefore, LPS-induced production of $\mathrm{NO}$ in murine macrophage RAW 264.7 cells was used for screening useful compounds for the development of new anti-inflammatory agents. The inhibition of NO production of compounds $\mathbf{1 0}$ and $\mathbf{1 1}$ is shown in Table 1. Compound $\mathbf{1 0}$ strongly inhibited NO production in LPS-stimulated RAW 264.7 cells in a dose-dependent manner with an $\mathrm{IC}_{50}$ value of $7.53 \pm 0.28 \mu \mathrm{g} /$ $\mathrm{mL}$. The positive control L-NMMA exhibited its $\mathrm{IC}_{50}$ value of $8.21 \pm 0.84 \mu \mathrm{g} / \mathrm{mL}$. Cytotoxicity of $\mathbf{1 0}$ was observed at the active concentrations; the cell viability was $43.27 \%$ at $4 \mu \mathrm{g} /$ $\mathrm{mL}$ (NO inhibition: $93.83 \%$ ), but up to $85.64 \%$ at $0.8 \mu \mathrm{g} / \mathrm{mL}$ (NO inhibition: $85.02 \%$ ) (Table 1 ). Therefore, the dose must be adjusted to a suitable level to balance drug safety and effective suppression of inflammatory responses. Previously, 10 was reported to show strong anti-inflammatory activity through the inhibition of IL- 8 and TNF- $\alpha$ release in lipopolysaccharide- (LPS-) stimulated human neutrophils [14]. Altogether, the results demonstrated the promise of $\mathbf{1 0}$ as a lead compound towards inflammation. Compound $\mathbf{1 1}$ did not display potent suppression on $\mathrm{NO}$ production at all concentrations tested $(0.4,8,20$, and $100 \mu \mathrm{g} / \mathrm{mL})$. The highest inhibition of NO production was $48.02 \%$ at $100 \mu \mathrm{g} /$ $\mathrm{mL}$ with the cell viability reaching 95.25\%. Among the isolates 1-17, the inhibition of NO generation, inflammatory cytokines, tumor necrosis factor- $\alpha$, or COX-2 enzyme was reported for triterpenes 1-4 [40-42], phytosterols 5-7 [43], and phenolic compounds 12 and 15 [44, 45]. The other compounds are not the major ones in the extracts and may not affect the overall anti-inflammatory property of the extracts.

3.3. Cytotoxic Activity of Compounds 10 and 11 . NTERA-2 is an embryonal carcinoma cell line, which expresses a gene profile related to pluripotency of stem cells such as OCT3/4 and SSEA-4. The cell line presents a lot of early embryo antigens that could be used to identify undifferentiated human embryonic stem cell (hESC) $[46,47]$. In addition, this cell line is easy to culture and grows quickly in a medium without any additional growth supplements except FBS. Thus, this cell line was widely used as 
TABLE 1: NO-inhibitory activities of compounds $\mathbf{1 0}$ and $\mathbf{1 1 .}$

\begin{tabular}{|c|c|c|c|c|c|c|}
\hline \multirow{2}{*}{ Concentration $(\mu \mathrm{g} / \mathrm{mL})$} & \multicolumn{2}{|c|}{10} & \multicolumn{2}{|c|}{11} & \multicolumn{2}{|c|}{ L-NMMA } \\
\hline & $\%$ inhibition & $\%$ cell survival & $\%$ inhibition & $\%$ cell survival & $\%$ inhibition & $\%$ cell survival \\
\hline 100 & - & - & 48.02 & 95.25 & 92.07 & 89.43 \\
\hline 20 & - & - & 10.44 & 96.65 & 72.78 & 92.93 \\
\hline 4 & 93.83 & 43.27 & 3.08 & - & 30.21 & - \\
\hline 0.8 & 85.02 & 86.54 & -4.85 & - & 15.77 & - \\
\hline 0.16 & 25.11 & 96.58 & - & - & - & - \\
\hline 0.032 & 12.61 & 99.82 & - & - & - & - \\
\hline $\mathrm{IC}_{50}$ & $7.53 \pm 0.28$ & - & $>100$ & - & $8.21 \pm 0.84$ & - \\
\hline
\end{tabular}

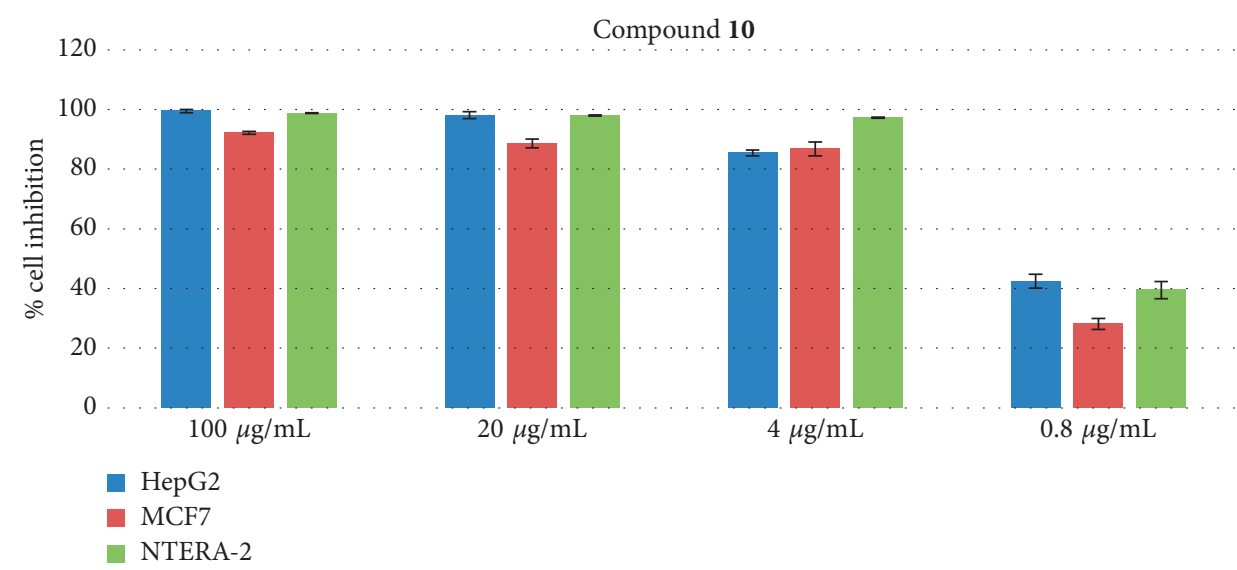

(a)

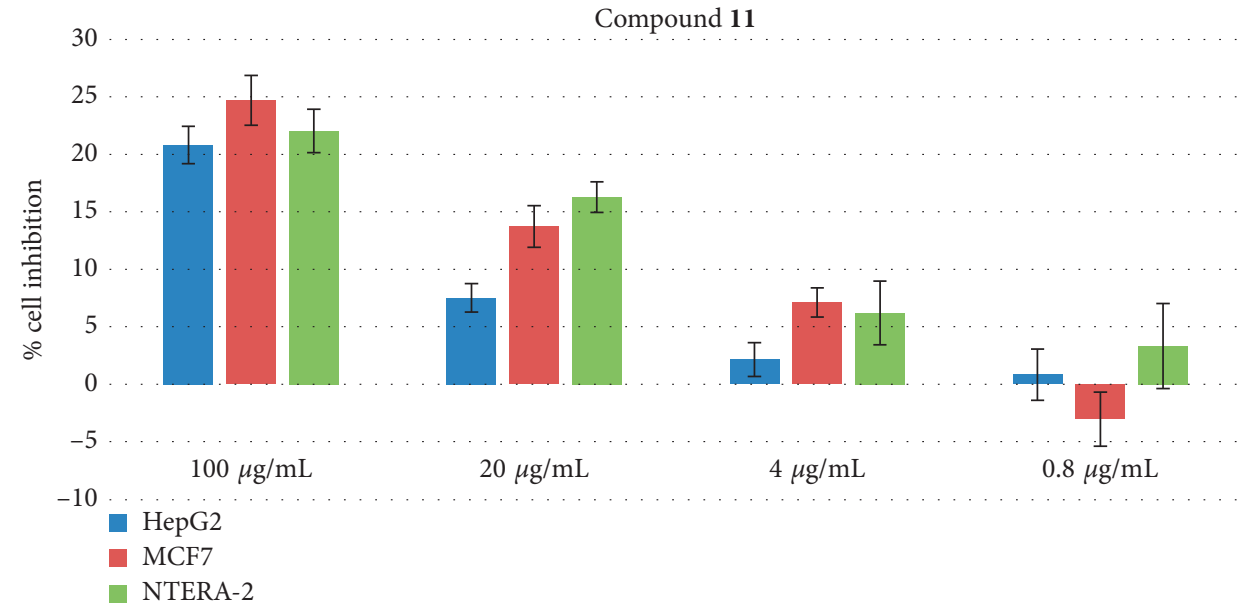

(b)

Figure 2: Effectiveness of compounds 10 and 11 on different cell lines, including CSCs. Cultured cells $\left(1 \times 10^{4}\right.$ cells/well) were treated with different concentrations of compounds ranging from $0.8 \mu \mathrm{g} / \mathrm{mL}$ to $100 \mu \mathrm{g} / \mathrm{mL}$. DMSO $1 \%$ served as the negative control. Each value represents the mean \pm SEM.

a model for CSC research in vitro and in discovering novel anticancer compounds against CSCs, a research area of great interest nowadays. The cytotoxicity of compounds $\mathbf{1 0}$ and 11 on human breast cancer cell line (MCF7), human hepatocellular carcinoma (HepG2), and pluripotent human embryonal carcinoma cell line (NTERA-2) was accessed using SRB assay. As shown in Figure 2 and Table 2, eupatoriopicrin (10) showed strong cytotoxic activity on all tested cell lines with $\mathrm{IC}_{50}$ values of $1.22 \pm 0.10 \mu \mathrm{g} / \mathrm{mL}$,
$0.94 \pm 0.12 \mu \mathrm{g} / \mathrm{mL}$, and $0.88 \pm 0.05 \mu \mathrm{g} / \mathrm{mL}$, respectively. Compound 11 did not show cytotoxic effects on HepG2, MCF-7, and NTERA-2 cell lines at the concentrations tested. Hitherto compound 10 expressed its cytotoxic activity against KB, HeLa, HL-60, EN19, EAT, P388, FIO 26, and L5178Y cell lines [28, 48, 49]. The structural requisite for the potent cytotoxic activity of $\mathbf{1 0}$ may be associated with its $\alpha$-methylene- $\gamma$-butyrolactone moiety [50]. The oncolytic activity was also demonstrated in an in vivo study 
TABle 2: Cytotoxic activities of compounds $\mathbf{1 0}$ and $\mathbf{1 1}$ on different cell lines.

\begin{tabular}{lccc}
\hline Samples & & Values of $\mathrm{IC}_{50}(\mu \mathrm{g} / \mathrm{mL})$ & NTERA-2 \\
\hline Compound 10 & HepG2 & MCF-7 & $0.88 \pm 0.05$ \\
Compound 11 & $0.94 \pm 0.12$ & $1.22 \pm 0.10$ & $>100$ \\
Ellipticine & $>100$ & $>100$ & $0.49 \pm 0.04$ \\
\hline
\end{tabular}

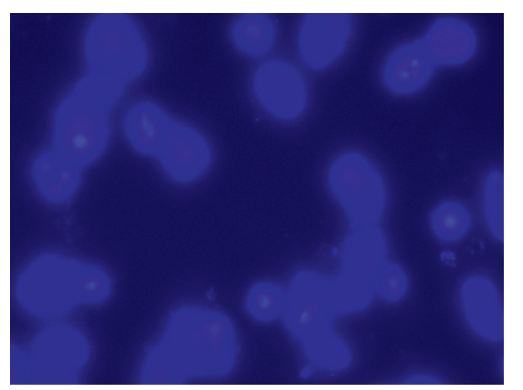

Compound $10(1 \mu \mathrm{g} / \mathrm{mL})$

(a)

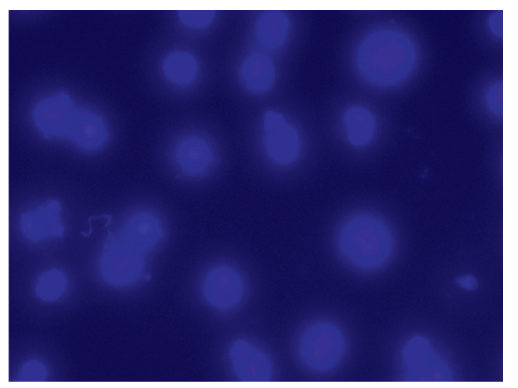

Compound $10(4 \mu \mathrm{g} / \mathrm{mL})$

(c)

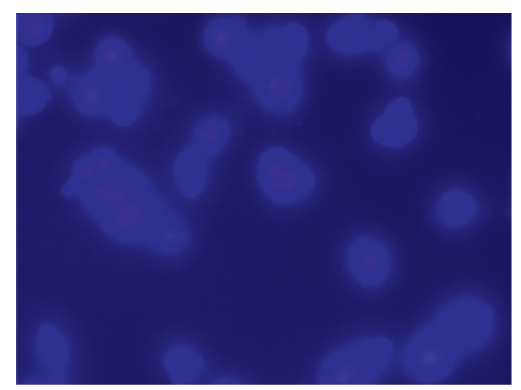

Compound $10(2 \mu \mathrm{g} / \mathrm{mL})$

(b)

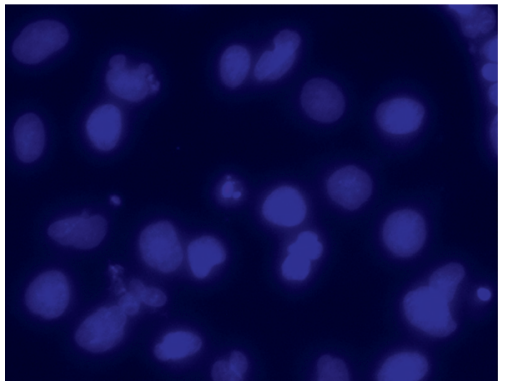

Negative control

(d)

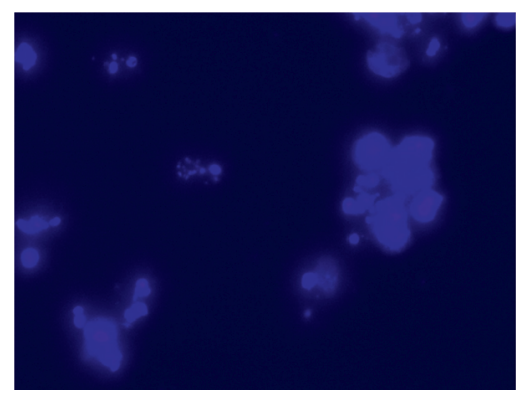

Camptothecin

(e)

FIGURE 3: Nuclear condensation and fragmentation effects of compound 10 on NTERA cells at different concentrations as $1 \mu \mathrm{g} / \mathrm{mL}, 2 \mu \mathrm{g} /$ $\mathrm{mL}$, and $4 \mu \mathrm{g} / \mathrm{mL}$ using Hoechst 33342 staining. The cells were at $48 \mathrm{~h}$ of incubation and observed with Zeiss Vert A1 inverted microscope $(100 x)$.

showing the tumor growth delay after administration of eupatoriopicrin $[51,52]$. The present study is the first report on the cytotoxicity of $\mathbf{1 0}$ against human CSCs (NTERA-2) as well as human cancer cell lines HepG2 and MCF-7. Glutathione (GSH) depletion is a central signaling event that regulates the activation of cell death pathways [53]. An in vitro study by Woerdenbag et al. showed that significant GSH reduction began to occur with concentrations of eupatoriopicrin $\geq 1 \mu \mathrm{g} / \mathrm{mL}$ in FIO 26 cells [52]. Eupatoriopicrin may react with the sulfhydryl group of cellular GSH to form a Michael adduct and its cytotoxicity may increase by the action of GSH depletion. Two other distinct pathways of cell death are apoptosis and necrosis. To investigate the possibility of apoptosis in the cytotoxicity of $\mathbf{1 0}$, we assayed further the apoptosis-inducing activity of $\mathbf{1 0}$ in NTERA-2 cells. 
TABLE 3: Percentage of apoptosis cells induced by compound 10 on NTERA-2 cells.

\begin{tabular}{lccc}
\hline Concentration $(\mu \mathrm{g} / \mathrm{mL})$ & \multicolumn{2}{c}{$\begin{array}{c}\text { apoptosis cells } \\
\text { Camptothecin }(5 \mu \mathrm{M})\end{array}$} & Negative control \\
\hline 4 & $\mathbf{1 0}$ & $84.85 \pm 5.38$ & $4.14 \pm 1.43$ \\
2 & $47.29 \pm 5.43$ & - & - \\
1 & $29.65 \pm 5.58$ & - & - \\
\hline
\end{tabular}

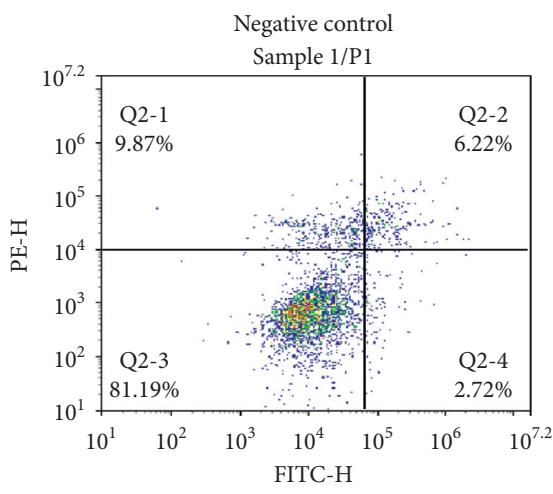

(a)

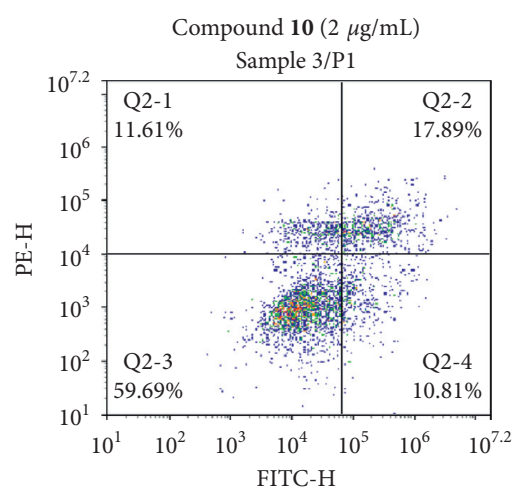

(c)

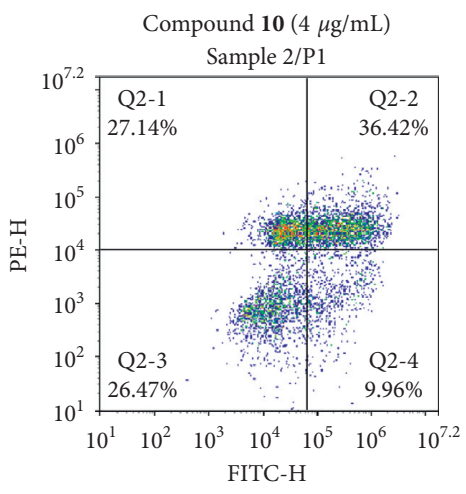

(b)

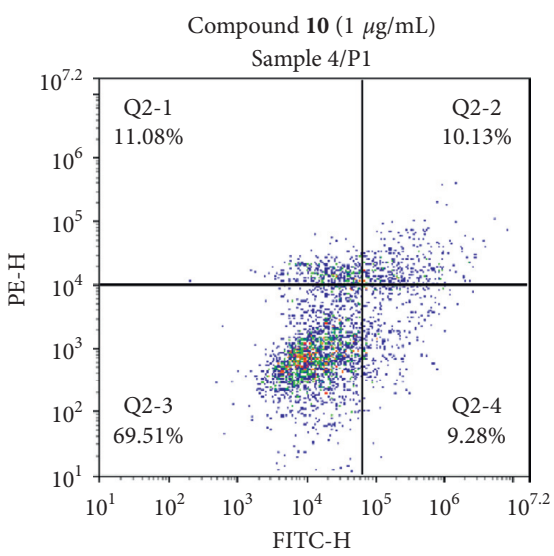

(d)

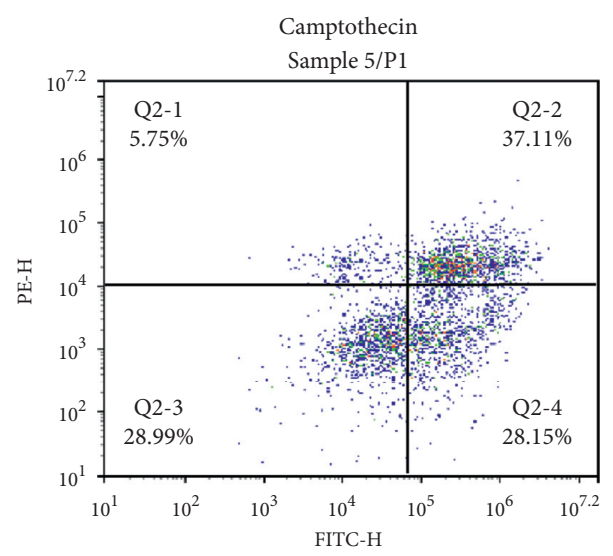

(e)

FIGURE 4: Flow cytometry analysis of apoptosis-inducing activities of compound 10 at different concentrations ranging as $1 \mu \mathrm{g} / \mathrm{mL}, 2 \mu \mathrm{g} / \mathrm{mL}$, and $4 \mu \mathrm{g} / \mathrm{mL}$ on NTERA-2 cells after $48 \mathrm{~h}$ incubation, using NovoCyte flow cytometry system and NovoExpress software (ACEA Bioscience, Inc.). 


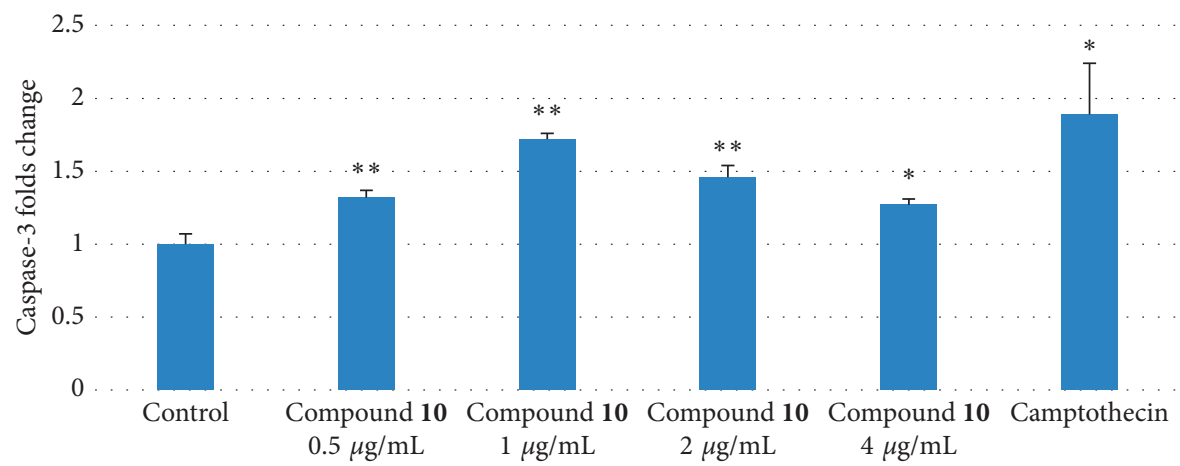

Figure 5: Caspase-3 inducible effects of compound $\mathbf{1 0}$ at different concentrations ranging from $0.5 \mu \mathrm{g} / \mathrm{mL}$ to $4 \mu \mathrm{g} / \mathrm{mL}$ on NTERA-2 cells after $48 \mathrm{~h}$ incubation. Diluted solution DMSO $1 \%$ served as the negative control. Each value represents the mean \pm SEM. ${ }^{* *} p<0.01$ and ${ }^{*} p<0.05$ compared to the negative control.

3.4. Apoptosis-Inducing Activity of Compound 10. One of the promising strategies for the identification of cytotoxicity of anticancer compounds is the induction of apoptosis of cancer cells. Based on the strong cytotoxicity of compound $\mathbf{1 0}$ on NTERA-2 CSC line, $\mathbf{1 0}$ was further evaluated for its apoptosis-inducing activity to better understand the possible apoptosis pathway. We examined the possible induction of apoptotic cell death by $\mathbf{1 0}$ using flow cytometry analysis and activation of caspase- 3 in CSCs. Thus, NTERA-2 cancer cells were treated with $\mathbf{1 0}$ and stained with Hoechst 33342. Using this nuclear staining dye, apoptotic cells with condensed and fragmented nuclei were detected, while most negative control cells showed nuclei with homogeneously staining morphology (Figure 3). The experiment exhibited that compound 10 could induce apoptosis on NTERA-2 cells in a dose-dependent manner (Table 3), resulting in the inhibition of the proliferation of NTERA-2 cells.

The flow cytometric analysis confirmed the apoptosisinducing activity of compound 10. As shown in Figure 4, the number of apoptotic cells, which was positive with Annexin $\mathrm{V}$, increased along with raising concentrations of $\mathbf{1 0}$. At the highest concentration, $4 \mu \mathrm{g} / \mathrm{mL} \mathbf{1 0}$ could induce up to $44.38 \%$ of apoptotic cells, while the anticancer drug camptothecin induced $65.26 \%$ of apoptotic cells. However, compound $\mathbf{1 0}$ also caused necrosis at this concentration, which was $27.14 \%$. The necrosis was reduced when cells were exposed to lower concentrations of $\mathbf{1 0}$ such as 1.0 and $2.0 \mu \mathrm{g} /$ $\mathrm{mL}$; meanwhile, the apoptosis-inducing activity of $\mathbf{1 0}$ was maintained at 19.41 and $28.70 \%$, respectively. The results indicated that the induction of apoptosis could be a mechanism of the cytotoxicity of $\mathbf{1 0}$ against NTERA-2 cancer cells.

In order to confirm the apoptosis-inducing activity of compound 10 towards CSCs, caspase-3 activity was measured. The initiator phase of apoptosis is characterized by initiator caspase (cysteine-dependent aspartate-directed protease) activation (Franco and Cidlowski). Caspase- 3 is one of the key enzymes in apoptosis and is activated in both the intracellular and extracellular apoptotic pathways $[54,55]$. This enzyme specifically activates the caspase-activated DNAse which causes chromosomal degradation and condensation in the nucleus, which are important feature characteristics of apoptosis [56]. Compound $\mathbf{1 0}$ significantly induced caspase- 3 production at all tested concentrations $(p<0.05)$ (Figure 5). Thus, compound 10 induced apoptosis in NTERA-2 cancer cells by the activation of caspase-3. However, the strongest activity was observed at the concentration of $1.0 \mu \mathrm{g} / \mathrm{mL}(p<0.01)$. Higher or lower concentrations also mediated caspase- 3 production but the induction was not as strong as that at $1.0 \mu \mathrm{g} / \mathrm{mL}$. These results indicated that this concentration might be the optimized concentration of $\mathbf{1 0}$ to induce apoptosis in the NTERA-2 CSC line through the activation of caspace-3.

Throughout, 10 expressed the potential activity against CSCs by apoptosis and/or necrosis induction. A challenge of cancer therapy is multidrug resistant, which is closely related to CSCs [57]. Multidrug resistance of CSCs is caused by multiple reasons such as overexpression of ATP-binding cassette $(\mathrm{ABC})$ transporters, high level of multidrug resistance (MDR), or detoxification proteins. The high survival capacity of CSCs under the treatment of drugs is caused by induced apoptosis resistance through changing a series of apoptosis mechanisms as downregulation p53 gene, miRNA action, or inhibiting apoptotic proteins [58-60]. Therefore, drugs as $\mathbf{1 0}$ that reduce survival rates of CSCs and induce apoptosis attract considerable attention.

\section{Conclusions}

In this study, 15 compounds out of 17 isolates were isolated for the first time from E. japonicum. Belonging to the privileged group of anti-inflammatory and anticancer structures, two sesquiterpene lactones $\mathbf{1 0}$ and $\mathbf{1 1}$ were selected for biological assays. Eupatoriopicrin (10) was found to strongly inhibit NO production, MCF-7, HepG2, and NTERA-2 cancer cell lines; meanwhile, compound 11 was not active. The cytotoxicity on the NTERA-2 cancer cell line is related to significant apoptosis induction by the action of $\mathbf{1 0}$ in the concentration- and caspase-dependent manners. The importance of the findings is that the study provides a chemical and biological basis for developing new approaches to explore therapeutic values of extracts or herbal medicines containing the herb E. japonicum. In addition, anti-inflammatory and anticancer botanical drugs enriched with bioactive constituents can be formulated and prepared from E. japonicum. Eupatoriopicrin (10) is also exposed in the 
study as a lead compound targeting inflammation or cancer diseases. Further projects on the synthesis of chemical derivatives or analogs of $\mathbf{1 0}$ addressing optimization of drug safety and effectiveness in combating inflammatory or cancer diseases are underway.

\section{Data Availability}

The data used to support the findings of this study are available from the corresponding author upon request.

\section{Conflicts of Interest}

The authors declare no conflicts of interest.

\section{Authors' Contributions}

Minh Giang Phan carried out extraction of plant material, isolation of compounds, structure determination, and preparation of the manuscript. Thi Viet Huong Do, Minh Trang Vu, and Ngoc Phuc Dong contributed to the isolation of compounds. Thi Thao Do and Thi Nga Nguyen evaluated biological activities and contributed to the preparation of the manuscript. All the authors have read the final manuscript and approved the submission.

\section{Acknowledgments}

This research was funded by the Vietnam National Foundation for Science and Technology Development (NAFOSTED) under Grant no. 104.01-2017.41.

\section{Supplementary Materials}

Experimental details and MS and NMR spectra of compounds 1-17 are freely available along with the manuscript as supplementary materials. (Supplementary Materials)

\section{References}

[1] P. M. Giang, V. M. Trang, D. T. V. Huong, S. Kawakami, and H. Otsuka, "Thymol derivatives from Eupatorium fortunei," Records of Natural Products, vol. 13, no. 5, pp. 434-439, 2019.

[2] D. T. V. Huong, P. M. Giang, and V. M. Trang, "Coumarins and polar constituents from Eupatorium triplinerve and evaluation of their $\alpha$-glucosidase inhibitory activity," Journal of Chemistry, vol. 2020, Article ID 8945063, 8 pages, 2020.

[3] P. Y. Liu, D. Liu, W. H. Li et al., "Chemical constituents of plants from the genus Eupatorium (1904-2014)," Chemistry \& Biodiversity, vol. 12, pp. 1481-1515, 2015.

[4] J. I. Shin, Y. J. Jeon, S. Lee et al., "Apoptotic and anti-inflammatory effects of Eupatorium japonicum Thunb. in rheumatoid arthritis fibroblast-like synoviocytes," BioMed Research International, vol. 2018, Article ID 1383697, 11 pages, 2018.

[5] http://ydvn.net/contents/view/3632.cay-son-lan-eupatoriumjaponicum.html.

[6] S. Nakajima and K. Kawazu, "Coumarin and euponin, two inhibitors for insect development from leaves of Eupatorium japonicum," Agricultural and Biological Chemistry, vol. 44, no. 12, pp. 2893-2899, 1980.
[7] J. A. Edgar, H. J. Lin, C. R. Kumana, and M. M. T. Ng, "Pyrrolizidine alkaloid composition of three Chinese medicinal herbs, Eupatorium cannabinum, E. japonicum and Crotalaria assamica," The American Journal of Chinese Medicine, vol. 20, no. 3-4, pp. 281-288, 1992.

[8] Y. G. Tian, H. W. Guo, Y. H. Liu et al., "Isolation and identification of chemical constituents in the flowers of Eupatorium japonicum," Natural Product Research and Development, vol. 32, pp. 607-612, 2020.

[9] P. M. Giang and H. Otsuka, "New compounds and potential candidates for drug discovery from medicinal plants of Vietnam," Chemical and Pharmaceutical Bulletin, vol. 66, no. 5, pp. 493-505, 2018.

[10] G. Dai, C. Wang, W. Tang, J. Liu, and B. Xue, “A 90-day oral toxicity study of the ethanol extract from Eupatorium japonicum Thunb and Foeniculum vulgare in rats," BioMed Research International, vol. 2020, Article ID 6859374, 8 pages, 2020.

[11] M.-J. Kim, W.-S. Jang, I.-K. Lee et al., "Reciprocal regulation of adipocyte and osteoblast differentiation of mesenchymal stem cells by Eupatorium japonicum prevents bone loss and adiposity increase in osteoporotic rats," Journal of Medicinal Food, vol. 17, no. 7, pp. 772-781, 2014.

[12] G.-J. Gu, S.-I. Ahn, S. J. Lim et al., “Eupatorium japonicum extract regulates inflammation through suppression of the TRIF-dependent signaling pathway of toll-like receptors," Food Science and Biotechnology, vol. 23, no. 2, pp. 587-592, 2014.

[13] H.-N. Lee, D.-Y. Lim, S.-S. Lim, and J.-D. Kim, "Anti-inflammatory effect of ethanol extract from Eupatorium japonicum," Korean Journal of Food Science and Technology, vol. 43, no. 1, pp. 65-71, 2011.

[14] E.-Y. Woo, S.-Y. Park, S.-J. Kwon et al., "Effect of Eupatorium japonicum extract on the metastasis, invasion and adhesion of MDA-MB-231 human breast cancer cells," Korean Journal of Food Science and Technology, vol. 43, no. 2, pp. 213-219, 2011.

[15] B. Michalak, J. P. Piwowarski, S. Granica et al., "Eupatoriopicrin inhibits pro-inflammatory functions of neutrophils via suppression of IL- 8 and TNF-alpha production and $p 38$ and ERK 1/2 MAP kinases," Journal of Natural Products, vol. 82, no. 2, pp. 375-385, 2019.

[16] X. Zhang, C. Fan, Y. Xiao, and X. Mao, "Anti-inflammatory and antiosteoclastogenic activities of parthenolide on human periodontal ligament cells in vitro," Evidence-based Complementary and Alternative Medicine, vol. 2014, Article ID 546097, 11 pages, 2014.

[17] Y. D. Yoo, D. H. Han, J. M. Jang et al., "Molecular characteristics of cancer stem-like cells derived from human breast cancer cells," Anticancer Research, vol. 33, no. 3, pp. 763-777, 2013.

[18] R. B. Moharil, A. Dive, S. Khandekar, and A. Bodhade, "Cancer stem cells: an insight," Journal of Oral and Maxillofacial Pathology, vol. 21, no. 3, p. 463, 2017.

[19] W. F. Taylor and E. Jabbarzadeh, "The use of natural products to target cancer stem cells," American Journal of Cancer Research, vol. 7, no. 7, pp. 1588-1605, 2017.

[20] N. R. Bernardes, M. Heggdorne-Araújo, I. F. J. C. Borges et al., "Nitric oxide production, inhibitory, antioxidant and antimycobacterial activities of the fruits extract and flavonoid content of Schinus terebinthifolius," Revista Brasileira de Farmacognosia, vol. 24, no. 6, pp. 644-650, 2014.

[21] S. Cheenpracha, E.-J. Park, B. Rostama, J. Pezzuto, and L. C. Chang, "Inhibition of nitric oxide (NO) production in lipopolysaccharide (LPS)-activated murine macrophage RAW 
264.7 cells by the norsesterterpene peroxide, epimuqubilin A," Marine Drugs, vol. 8, no. 3, pp. 429-437, 2010.

[22] P. Skehan, R. Storeng, D. Scudiero et al., "New colorimetric cytotoxicity assay for anticancer-drug screening," JNCI Journal of the National Cancer Institute, vol. 82, no. 13, pp. 1107-1112, 1990.

[23] S. Allen, J. Sotos, M. J. Sylte, and C. J. Czuprynski, "Use of Hoechst 33342 staining to detect apoptotic changes in bovine mononuclear phagocytes infected with Mycobacterium avium subsp. paratuberculosis," Clinical Diagnostic Laboratory Immunology, vol. 8, no. 2, pp. 460-464, 2001.

[24] Q. A. Ngo, T. H. N. Thi, M. Q. Pham, D. Delfino, and T. T. Do, "Antiproliferative and antiinflammatory coxib-combretastatin hybrids suppress cell cycle progression and induce apoptosis of MCF7 breast cancer cells," Molecular Diversity, vol. 2020, 2020.

[25] C. Chu, J. Xu, D. Cheng et al., "Anti-proliferative and apoptosis-inducing effects of camptothecin-20(S)-O-(2-pyrazolyl-1)acetic ester in human breast tumor MCF-7 cells," Molecules, vol. 19, no. 4, pp. 4941-4955, 2014.

[26] L. J. Goad and T. Akihisha, Analysis of Sterols, Blackie Academic \& Professional, London, UK, 1997.

[27] V. Spitzer, "High-resolution nuclear magnetic resonance spectroscopy of fatty acids and lipids," GIT Laboratory Journal, vol. 1998, pp. 45-47, 1998.

[28] M. Tori, Y. Takeichi, H. Kuga, K. Nakashima, and M. Sono, "Seven germacranolides, eupaglehnins A, B, C, D, E, and F, and $2 \alpha$-acetoxyepitulipinolide from Eupatorium glehni," Chemical and Pharmaceutical Bulletin, vol. 50, no. 9, pp. 1250-1254, 2002.

[29] M. Tori, N. Morishita, N. Hirota et al., "Sesquiterpenoids isolated from Eupatorium glehnii. Isolation of guaiaglehnin A, structure revision of hiyodorilactone $\mathrm{B}$, and genetic comparison," Chemical and Pharmaceutical Bulletin, vol. 56, no. 5, pp. 677-681, 2008.

[30] A. N. de Gutierrez, A. Bardón, C. A. N. Catalán, T. B. Gedris, and W. Herz, "Sesquiterpene lactones and other constituents of Disynaphia multicrenulata from Argentina," Biochemical Systematics and Ecology, vol. 29, no. 6, pp. 633-647, 2001.

[31] G. Lang, C. M. Passreiter, B. E. Medinilla, and J.-J. Castillo, "Further sesquiterpene lactones from Eupatorium semialatum," Pharmaceutical Biology, vol. 39, no. 5, pp. 332-335, 2001.

[32] S. W. Chang, K. H. Kim, I. K. Lee, S. U. Choi, S. Y. Ryu, and K. R. Lee, "Phytochemical constituents of Bistorta manshuriensis," Natural Products Sciences, vol. 15, pp. 234-240, 2009.

[33] R. D. Stolow and K. Sachdev, "The p-menth-1-ene-3,6-diols," Tetrahedron, vol. 21, no. 7, pp. 1889-1895, 1965.

[34] Ş. Georgeta, P. I. Ana, H. Tünde, and B. Sanda, The isolation and identification of rutin from pharmaceutical products," Analele Universităţii din Oradea, Fascicula: Ecotoxicologie, Zootehnie şi Tehnologii de Industrie Alimentară, vol. 15, pp. 109-114, 2016.

[35] L. Krenn, A. Miron, E. Pemp, U. Petr, and B. Kopp, "Flavonoids from Achillea nobilis L." Zeitschrift für Naturforschung C, vol. 58, no. 1-2, pp. 11-16, 2003.

[36] I. Macedo, J. H. da Silva, P. T. da Silva et al., "Structural and microbiological characterization of 5-hydroxy-3, 7, 4'-trimethoxyflavone: a flavonoid isolated from Vitex gardneriana Schauer leaves," Microbial Drug Resistance, vol. 25, no. 3, pp. 434-438, 2019.
[37] D. G. Hirst and T. Robson, "Nitric oxide physiology and pathology," Methods in Molecular Biology, vol. 704, pp. 1-13, 2011.

[38] B. J. R. Whittle, "Nitric oxide in physiology and pathology," The Histochemical Journal, vol. 27, no. 10, pp. 727-737, 1995.

[39] H. Nagai, H. Kumamoto, M. Fukuda, and T. Takahashi, "Inducible nitric oxide synthase and apoptosis-related factors in the synovial tissues of temporomandibular joints with internal derangement and osteoarthritis," Journal of Oral and Maxillofacial Surgery, vol. 61, no. 7, pp. 801-807, 2003.

[40] J. Taira, H. Nanbu, and K. Ueda, "Nitric oxide-scavenging compounds in Agrimonia pilosa Ledeb on LPS-induced RAW264.7 macrophages," Food Chemistry, vol. 115, no. 4, pp. 1221-1227, 2009.

[41] P. D. O. de Almeida, A. P. de A. Boleti, A. L. Rüdiger, G. A. Lourenço, V. F. da Veiga Junior, and E. S. Lima, "Antiinflammatory activity of triterpenes isolated from Protium paniculatum oil-resins," Evidence-Based Complementary and Alternative Medicine, vol. 2015, Article ID 293768, 10 pages, 2015.

[42] V. R. Askari, N. Fereydouni, V. Baradaran Rahimi et al., " $\beta$-Amyrin, the cannabinoid receptors agonist, abrogates mice brain microglial cells inflammation induced by lipopolysaccharide/interferon- $\gamma$ and regulates $\mathrm{M} \varphi 1 / \mathrm{M} \varphi 2$ balances," Biomedicine \& Pharmacotherapy, vol. 101, pp. 438-446, 2018.

[43] A. Romero-Estrada, A. Maldonado-Maganã, J. GonzálezChristen, S. M. Bahena, M. L. Garduno-Ramírez, and V. Rodríguez-López, "Anti-inflammatory and antioxidative effects of six pentacyclic triterpenes isolated from the Mexican copal resin of Bursea copalifera," BMC Complementary and Alternative Medicine, vol. 16, p. 422, 2016.

[44] H. L. Zhang, X. Q. Gan, Q. F. Fan et al., "Chemical constituents and anti-inflamatory activities of Maqian (Zanthoxylum myriacanthum var. pubescens) bark extracts," Scientific Reports,vol. 7, p. 45805, 2017.

[45] C. Guruvayoorappan and G. Kuttan, "Rutin inhibits nitric oxide and tumor necrosis factor-alpha production in lipopolysaccharide and concanavalin-a stimulated macrophages," Drug Metabolism and Drug Interactions, vol. 22, no. 4, pp. 263-278, 2007.

[46] T. Ogiwara, K. Satoh, T. Negoro, H. Okayasu, H. Sakagami, and S. Fujisawa, Inhibition of NO production by activated macrophages by phenolcarboxylic acid monomers and polymers with radical scavenging activity," Anticancer Research, vol. 23, no. 2B, pp. 1317-1323, 2003.

[47] S. Ali Azouaou, F. Emhemmed, N. Idris-Khodja et al., "Selective ROS-dependent $p 53$-associated anticancer effects of the hypoxoside derivative rooperol on human teratocarcinomal cancer stem-like cells," Investigational New Drugs, vol. 33, no. 1, pp. 64-74, 2015.

[48] R. Josephson, G. Sykes, Y. Liu et al., "A molecular scheme for improved characterization of human embryonic stem cell lines," BMC Biology, vol. 4, p. 28, 2006.

[49] A. C. Beekman, H. J. Woerdenbag, H. H. Kampinga, and A. W. T. Konings, "Cytotoxicity of artemisinin, a dimer of dihydroartemisinin, artemisitene and eupatoriopicrin as evaluated by the MTT and clonogenic assay," Phytotherapy Research, vol. 10, no. 2, pp. 140-144, 1996.

[50] H. J. Woerdenbag, H. Hendriks, T. M. Malingré, R. Van Stralen, K. J. Van den Berg, and A. W. T. Konings, "In vitro cytotoxicity of sesquiterpene lactones from Eupatorium cannabinum L. and semi-synthetic derivatives from eupatoriopicrin," Phytotherapy Research, vol. 2, no. 3, pp. 109-114, 1988. 
[51] N. Vongvanich, P. Kittakoop, P. Charoenchai, S. Intamas, K. Sriklung, and Y. Thebtaranonth, "Antiplasmodial, antimycobacterial, and cytotoxic principles from Camchaya calcarea," Planta Medica, vol. 72, no. 15, pp. 1427-1430, 2006.

[52] H. J. Woerdenbag, W. Lemstra, H. Hendriks, T. M. Malingré, and A. W. Konings, "Investigation of the anti-tumor action of eupatoriopicrin against the Lewis lung tumour," Planta Medica, vol. 53, no. 4, pp. 518-522, 1987.

[53] H. Woerdenbag, W. Lemstra, T. M. Malingré, and A. Konings, "Enhanced cytostatic activity of the sesquiterpene lactone eupatoriopicrin by glutathione depletion," British Journal of Cancer, vol. 59, no. 1, pp. 68-75, 1989.

[54] R. Franco and J. A. Cidlowski, "Glutathione efflux and cell death," Antioxidants \& Redox Signaling, vol. 17, no. 12, pp. 1694-1713, 2012.

[55] A. G. Porter and R. U. Jänicke, "Emerging roles of caspase-3 in apoptosis," Cell Death \& Differentiation, vol. 6, no. 2, pp. 99-104, 1999.

[56] N. Singh and K. Bose, "Apoptosis: pathways, molecules and beyond," in Proteases in Apoptosis: Pathways, Protocols and Translational Advances, K. Bose, Ed., Springer, Berlin, Germany, pp. 1-30, 2015.

[57] D. Lechardeur, M. Xu, and G. L. Lukacs, "Contrasting nuclear dynamics of the caspase-activated DNase (CAD) in dividing and apoptotic cells," Journal of Cell Biology, vol. 167, no. 5, pp. 851-862, 2004.

[58] S. Bao, Q. Wu, R. E. McLendon et al., "Glioma stem cells promote radioresistance by preferential activation of the DNA damage response," Nature, vol. 444, no. 7120, pp. 756-760, 2006.

[59] M. Prieto-Vila, R.-U. Takahashi, W. Usuba, I. Kohama, and T. Ochiya, "Drug resistance driven by cancer stem cells and their niche," International Journal of Molecular Sciences, vol. 18, no. 12, p. 2574, 2017.

[60] W. Si, J. Shen, H. Zheng, and W. Fan, "The role and mechanisms of action of microRNAs in cancer drug resistance," Clinical Epigenetics, vol. 11, p. 25, 2019. 